\title{
Thailand's Policy and Law on Atmosphere Management for People's Welfare: The Fight Against Climate Change
}

\author{
Peerapon Jaderojananont \\ Macquarie University Australia \\ peerapon.jaderojananont@students.mq.edu.au
}

\begin{abstract}
It is true that climate change has become a common concern of mankind which does not adversely affect any country in isolation, but affects the global community as a whole. As provided by international framework, climate change should be mitigated by the stabilization of greenhouse gas concentrations in the atmosphere at a safe and appropriate level. Although Thailand is not one of the industrialized countries contributing to greenhouse gas emissions, it should act to cooperate with other countries to comply with the international framework. This article focuses on exploring and examining policy and law adopted by Thailand to reduce greenhouse gas emissions in order to prove that Thailand has high potential to comply and cooperate with the global community. This will reflect the substantial creation of a low carbon society in Thailand where Thai people will finally be secured against the dangerous anthropogenic interference with the Earth's climate system.
\end{abstract}

Keywords: Thailand's Policy and Law, Climate Change, Atmosphere Management

\section{A. Introduction}

Despite the fact that Thailand is one of the Non-Annex 1 parties 
to the United Nations Framework Convention on Climate Change (UNFCCC), it is believed that Thailand likely has the potential to implement, through its policy and law, the UNFCCC's objectives and to build a low carbon society. The core theme of 'atmosphere management' in this article refers only to the stabilization of greenhouse gas concentrations in the atmosphere at a safe and appropriate level in order to mitigate climate crisis and promote people's welfare. This article aims to explore and examine Thailand's policy and law adopted to respond to climate crisis in accordance with the UNFCCC. Thailand's practices relating to climate change will be introduced and examined through three key aspects: (1) policy aspect, (2) legal aspect, and (3) institutional aspect.

As is commonly known, it is impossible to live without air. Air or atmosphere is the layer of gases which naturally surround our planet to sustain life, protect all living things from harmful solar radiation, and regulate the global climate. ${ }^{1}$ Although air or atmosphere is a non-exhausting natural resource like water, it may be contaminated by several pollutants. In addition to air pollution, we may see continued increases in greenhouse gases (GHGs) in the atmosphere which are mostly attributed to human activities. As reported by the IPCC Working Group I ${ }^{2}$, the Earth's climate system is generally powered by solar radiation and the Earth's temperature has been relatively constant over many centuries because incoming solar energy has been nearly in balance with outgoing radiation. ${ }^{3}$ While GHGs in-

1 Alexandre Kiss and Dinah Shelton, Guide to International Environmental Law, Martinus Nijhoff Publisher, 2007, p. 160.

2 The Intergovernmental Panel on Climate Change (IPCC) established by the United Nations Environment Program (UNEP) and the World Meteorological Organization (WMO) is the leading international body for the assessment of climate change which provides the global community with a clear scientific view and knowledge in climate change. The IPCC also established its Working Group I (WG I) for assessing the physical scientific basis of the climate system and climate change. See Intergovernmental Panel on Climate Change, "Organization” (1 August 2018), http:/ / www.ipcc.ch/ index.htm, accessed 1 August 2018.

3 Intergovernmental Panel on Climate Change, Climate Change 2013: The Physical Science Basis. Contribution of Working Group I to the Fifth Assessment Report of the Intergovernmental Panel on Climate Change, Cambridge Univer- 
cluding water vapour, carbon dioxide $\left(\mathrm{CO}_{2}\right)$, methane $\left(\mathrm{CH}_{4}\right)$, CFCs, nitrous oxide $\left(\mathrm{N}_{2} \mathrm{O}\right)$, and tropospheric ozone $\left(\mathrm{O}_{3}\right)$ are transparent to incoming shortwave solar radiation, the longwave solar radiation emitted by the Earth's surface is largely absorbed and trapped by those GHGs. ${ }^{4}$ Consequently, increases in atmospheric concentrations of GHGs result in the greenhouse effect. Resulting from the greenhouse effect, the global temperature has been dramatically increasing. As predicted by the IPCC, the anthropogenic warming is likely to lie in the range of 0.1-0.2 degrees Celsius per decade over the next few decades; moreover, this global warming stimulates a likelihood of increased precipitation and a greater risk of extreme weather conditions such as floods and droughts. ${ }^{5}$

Because of warmer ocean temperatures and the melting of glaciers and small ice caps, the effects of climate change are scientifically observed by a sea level rise, a decrease of snow and ice cover, and changes in aquatic and terrestrial ecosystems leading to other effects on forestry, agriculture, and human health. ${ }^{6}$ People in many countries have already suffered from the impacts of climate change which includes starvation, infectious disease, social collapse, and the disappearance of whole populations. ${ }^{7}$ In Thailand, it is reported that the annual average temperature rose by one degree Celsius from 1981 to $2007 .{ }^{8}$ As a largely agricultural country, Thailand has fought against saline invasion from the sea which has contaminated some underground water sources. Higher salt levels in the soil from coastal flooding is a critical problem for its agricultural sector. ${ }^{9}$ Climate change effects such as floods and droughts threaten food production

sity Press, 2013, p. 126.

4 Ibid.

5 Philippe Sands, Principles of International Environmental Law, second edition, Cambridge University Press, 2003, p. 358.

6 Margaret Rosso Grossman, "Climate Change and the Law," The American Journal of Comparative Law, Vol. 58, 2010, p. 223, 225.

7 World Health Organization, Climate Change and Human Health: Risks and Responses, World Health Organization, 2003, pp. 9-10.

8 Danny Marks, "Climate Change and Thailand: Impacts and Response," Contemporary Southeast Asia, Vol. 33, Num. 2, 2011, p. 229, 231.

9 Ibid, p. 233. 
and food security; moreover, changes in rainfall adversely affect water resource management for farmers, who consume 70 percent of Thailand's water supply. ${ }^{10}$

Due to these dangers of climate change, Thailand has been encouraged to mitigate such effects and undertake initiatives to control and manage atmospheric concentrations of GHGs, particularly $\mathrm{CO}_{2}$ emissions from a variety of activities. Because Thailand has ratified the UNFCCC since 28 December 1994 and the Kyoto Protocol since 28 August $2002^{11}$, Thailand is obligated to commit to the goals of the UNFCCC and Kyoto Protocol. Article 2 of the UNFCCC sets up the ultimate goal for all state parties by requesting them to stabilize GHGs concentrations in the atmosphere at a level that would prevent dangerous anthropogenic interference with the climate system within a time frame that accords with sustainable development principles. ${ }^{12}$ We should have realized that the convention does not need all state parties to prohibit GHGs emissions, but it encourages those parties to maintain an appropriate level of GHGs emissions with a balance between economic development and their adaptation. This goal is the key direction Thailand has attempted to implement in pursuit of limitation and decrease of GHGs including $\mathrm{CO}_{2}$ emissions within the country. This will also contribute to the substantial creation of a low carbon society in Thailand where Thai people will finally be secured against the dangerous anthropogenic interference with the Earth's climate system.

\section{B. Principles and Concepts}

Article 3 of the UNFCCC ${ }^{13}$ provides the principles and concepts which all state parties shall apply for their own policy and measures.

10 Ibid, p.234.

11 See United Nations Climate Changes, “Thailand” (10 September 2018), http://unfccc.int/tools_xml/country_TH.html, accessed 10 September 2018.

12 See United Nations Framework Convention on Climate Change, opened for signature 4 June 1992, 1771 UNTS 107 (entered into force 21 March 1994) art 2.

13 Ibid, art 3. 
Thailand recognizes and applies those principles as a platform for its policy and law on atmosphere management.

As provided by the UNFCCC, the first principle should be the protection of the Earth's climate system on the basis of equity, common but differentiated responsibilities, and respective capabilities. ${ }^{14}$ The concept of "common but differentiated responsibilities" should be particularly emphasized with Thailand's capabilities to fight against climate change since it refers to the shared responsibilities of all nations, where the contributions may be different depending on their capability to address environmental problems. ${ }^{15}$ Accordingly, Thailand would be required to reflect on its specific needs and circumstances before launching policy and legal measures which are practical and possible for its society. Thailand is a Non-Annex I developing country and does not possess any high technological or financial resources, so it really needs to support international cooperation and the transfer of technology with Annex I countries to implement its obligations.

As provided by Article 3 of the UNFCCC, precautionary measures should be taken by all state parties to anticipate and prevent the cause of climate change and mitigate its adverse effects. The "precautionary principle" helps us to avoid the possible effects of climate change as it enables regulators to act on the limits of current knowledge in the absence of full scientific certainty before any harm occurs. Thailand practices this principle with preference for preventive measures over remedial measures, establishing scientific organs to undertake research and development leading to considered policy and legal measures.

GHGs emissions are linked to human activity and economic development. As such, carbon dioxide is normally emitted by industrial operations, transportation and other combustion activities. It is not easy to decrease carbon dioxide emissions while such a decrease must not preclude economic growth. The UNFCCC requests all state par-

14 Ibid.

15 Organization for Economic Co-operation and Development, Environmental Principles and Concepts, OCDE/GD(95)124, Paris, 1995, p.7. 
ties to protect the Earth's climate system by promoting the concept of sustainable development. ${ }^{16}$ This concept was forged by the idea that our Earth has limited supplies and limited capacity to provide for human desires and to absorb human wastes. Many scholars have observed that continual economic growth adversely affects the environment and so it cannot be sustained forever. ${ }^{17}$ This concept, hence, supports the ways to sustain economic growth without creating too much pollution or environmental degradation. ${ }^{18}$ As a developing country, Thailand needs to promote its economic growth together with following its UNFCCC's commitments.

\section{Thailand and Its Commitments}

Thailand is one of the Non-Annex I countries which is obligated to implement the UNFCCC's commitments. Under Article 4 of the UNFCCC, it provides a framework for state parties which is divided into four categories in accordance with the principle of common but differentiated responsibilities. First of all, it requests all state parties to cooperate with each other to exchange information, and transfer necessary technology in conformity with the principle of sustainable development. ${ }^{19}$ The second and third categories provide that Annex I and Annex II countries shall take fully corresponding measures to assist developing countries in contributing to the achievement of the UNFCCC's objective. ${ }^{20}$ Lastly, most developing countries, being NonAnnex I countries, shall fully and effectively implement their own commitments while taking economic and social development and poverty eradication into account. ${ }^{21}$

It is noted that Thailand is not obligated to take the specific commitments that Annex I countries are, but Thailand shall attempt to decrease GHGs emissions by its development of national inventories

16 See UNFCCC, art 3.

17 Sharon Beder, Environmental Principles and Policies: An Interdisciplinary Introduction, Earthscan, 2006, pp.12-17.

18 Ibid.

19 See UNFCCC, art 4 paras 1, 8, 9, 10.

$20 \mathrm{Ibid}$, art 4 paras $2,3,4,5$.

$21 \mathrm{Ibid}$, art 4 para 7. 
of GHGs emissions. From sources and removal by sinks, a variety of national programs, policies and measures exist to mitigate climate change, including furthering public awareness and education. In 1997, the Kyoto Protocol was adopted to complement the UNFCCC and to support Annex I countries to accomplish their quantified emission limitation and reduction targets in order to promote sustainable development. ${ }^{22}$ Although the Kyoto Protocol does not provide specific target commitments for Thailand and other Non-Annex countries, Thailand and those countries may participate in the mechanisms created by the Protocol as an incentive for state parties to reduce GHGs emissions. There are three mechanisms under the Kyoto Protocol: Joint Implementation (JI), Clean Development Mechanism (CDM), and Emissions Trading (ET).

The reduction of Thailand's GHGs emissions is linked with the CDM because this mechanism encourages Non-Annex I countries to meet their general commitments and helps Annex I countries to comply with their quantified emission limitation and reduction commitments. ${ }^{23}$ The CDM establishes collaboration between Annex I and Non-Annex I countries by allowing GHGs emission reduction projects by Annex I countries to be implemented in Non-Annex I countries. In this regard, Annex I countries can earn certified emission reductions (CERs) credits arising from the projects which count towards meeting their quantified emission limitation and reduction commitments. ${ }^{24}$ Moreover, the CERs which are surplus from counting towards these quantified commitments may be traded in carbon markets. Thailand, as a Non-Annex I country, may directly benefit from CDM projects which result in transfer of technology and investments within the country. The ET is also relevant to Thailand's ca-

22 Kyoto Protocol to the United Nations Framework Convention on Climate Change, opened for signature 16 March 1998, 37 ILM 22 (entered into force 16 February 2005) art 3.

23 Ibid, art 12.

24 See United Nations Climate Changes, “The Clean Development Mechanism” (10 September 2018), https: / / unfccc.int/process-and-meetings/thekyoto-protocol/mechanisms-under-the-kyoto-protocol/the-clean-development-mechanism, accessed 10 September 2018. 
pabilities to mitigate climate change because Article 17of the Kyoto Protocol requests Annex I countries to control and limit their GHGs emissions in accordance with assigned amount units (AAUs) that each Annex I country is allowed. ${ }^{25}$ Through the carbon market, they need to buy carbon credits from other parties having surplus credits to redeem their extra AAUs. ${ }^{26}$ In doing so, Thailand may participate in the carbon market by selling carbon credits saved for trading.

\section{Thailand's Policies and Plans on GHGs Emissions Reduction}

Thailand has implemented a variety of policies and plans to reduce GHGs emissions. Thailand launched its updated climate change master plan for 2015-2050. This is a very long-term plan which is used to cover its substantive principles and practices. Thailand's subsidiary plans should be further adopted in accordance with such a master plan's direction. Thailand's National Committee on Climate Change recently approved the launch of the master plan, as presented by the Office of Natural Resources and Environmental Policy and Planning (ONEP), which has as its key objective to integrate relevant organizations with the committee's vision so that they would proceed its operation on the same way.

The master plan was adopted to respond to the UNFCCC's principles and concepts which emphasize the reduction of GHGs for pursuing sustainable development. Hence, it is important to realize a balance between economic development and environmental protection. The master plan's objective is not to prohibit GHGs emissions from internal activities, but it aims to stabilize GHGs emitted from them as per the committed level under the UNFCCC. This plan mainly consists of three strategies: (1) adaptation, (2) mitigation, and

25 Kyoto Protocol, art 17.

26 See United Nations Climate Changes, “Emissions Trading” (30 August 2018), https: / / unfccc.int/ process / the-kyoto-protocol/ mechanisms / emissionstrading, accessed 10 September 2018. and See also Thailand Greenhouse Gas Management Organization (Public Organization), "Carbon Market/ Carbon Credits and Carbon Market” (30 August 2018), http:/ / www.tgo. or.th $/ 2015$ / english / content.php?s1=35\&s2=80. accessed 30 August 2018. 
(3) promotion of Thailand's capability. ${ }^{27}$ In considering these strategies, Thailand has attempted to support the use of technology, investment, and human resources in order to undertake Measurement, Reporting, and Verification (MRV) in the country. The MRV reports that by 2020 Thailand will reduce GHGs emissions voluntarily by around $7-20 \%$ in the energy and transportation sectors. ${ }^{28}$

Moreover, as requested by the UNFCCC, Thailand reports a biennial update to the Conference of the Parties (COP). The report is a collection of information on mitigation actions and national inventory operated by two main organs. First of all, the Thailand Greenhouse Gas Management Organization (Public Organization), known as TGO, is responsible for technique and academic assistance to support ONEP. Secondly, ONEP is appointed as a national focal point taking responsibility for collecting the reports of GHGs emissions from other governmental organs so that it can produce the national inventory. ${ }^{29}$ We should have seen that Thailand has divided implementation of the UNFCCC into two key parts: (1) technique and academic components, and (2) operational activities. On the other hand, Thailand does not provide require the private sector to report their GHGs emissions. Thailand only requires the public sector to report voluntarily.

Thailand implements the MRV in two ways. The first is policybased mitigation activities which involve the stages of measurement, reporting, and mitigation assessment to demonstrate how Thailand can fulfil its master plan and meet its UNFCCC commitments. The second is relevant to the establishment of GHGs reduction projects (project-based mitigation actions ${ }^{30}$ which promotes investment into

27 Thailand Greenhouse Gas Management Organization (Public Organization), "GHG Situation/Policies and Plans" (20 September 2018), http:/ / www.tgo.or.th $/ 2015$ / english / content.php?s1 =32\&s2 =74\&sub3=sub3. accessed 20 September 2018.

28 Thailand Greenhouse Gas Management Organization (Public Organization), Nationally Appropriate Mitigation Actions, Thailand Greenhouse Gas Management Organization (Public Organization), 2015, p.76.

29 Ibid.

30 Ibid, p.77. 
projects leading to the reduction of GHGs emissions mainly regulated and permitted by the TGO. These project-based actions should be helpful to Thailand's standing towards UNFCCC and Kyoto Protocol commitments. As a Non-Annex I country, Thailand plays a role in convincing Annex I countries to invest in CDM projects within the country so that those countries will earn CERs credits from the projects, which count towards their quantified emissions limitation and reduction commitments. Thailand may also use this cooperative investment to be a channel for the transfer of technology.

In addition, Thailand's direction towards climate change mitigation was also restated by the Minister of Natural Resources and Environment who gave an important speech to COP 20. This speech emphasizes the significance of Thailand's adaptation to mitigate GHGs emissions by complying with sustainable development. ${ }^{31}$ In this regard, social, economic, and environmental aspects shall be reconciled to build its low-carbon society. ${ }^{32}$ The speech also specifies how Thailand will take actions to reduce GHGs emissions by $7 \%$ in its energy and transportation sectors by 2020 and probably up to $29 \%$ with international assistance. ${ }^{33}$ The Minister's speech to COP 20 was consistent with the master plan and its similar target of GHGs emissions reduction. Despite not having any specific commitments to the UNFCCC like Annex I countries, Thailand has established a timeframe and goal for climate change mitigation with regard to its capabilities and circumstances.

\section{E. Thailand's Laws Promoting GHGs Emissions Reduction}

Although Thailand launched its policies and plans on climate change in accordance with the UNFCCC, it has not enacted any specific law

31 Thailand Greenhouse Gas Management Organization (Public Organization), above $n 29$.

32 Ibid.

33 See Minister of Natural Resources and Environment's speech to the COP 20 at https://unfccc6.meta-fusion.com/cop20/events/2014-12-09-15-00conference-of-the-parties-cop-5th-meeting-conference-of-the-parties-serving-as-the-meeting-of-the-parties-to-the-kyoto-protocol-cmp-5th-meeting/ thailand 
which solely applies to climate change mitigation. We may, however, find some legislation responding to how GHGs concentrations in the atmosphere can be reduced. That legislation plays important roles in supporting renewable energy use and development as well as carbon sinks to absorb $\mathrm{CO}_{2}$ in the country.

\section{The Promotion of Energy Conservation Act B.E. 2535 (1992)}

This Act provides the definition of renewable energy as 'energy obtained from sources such as: wood, firewood, paddy husk, bagasse, biomass, hydro power, solar power, geothermal power, wind power, waves and tides'. ${ }^{34}$ The Act aims to provide incentives that are in the form of funds for promoting energy conservation as well as assistance measures to the owners of any factory or building who attempts to conserve and reduce the use of non-renewable energy. ${ }^{35}$ Hence, such incentives provided by this Act are available to convince those owners to pay attention to the use of renewable energy.

\section{The Energy Development and Promotion Act B.E. 2535 (1992)}

Additionally, this Act established the Department of Alternative Energy Development and Efficiency (DEDE), which functions to design, construct and maintain production, transmission and transformation of energy sources. This includes utilization of energy systems, such as new forms of renewable energy to generate electricity. ${ }^{36}$ Therefore, DEDE is a key public agency for promoting and strengthening renewable energy use in Thailand in order to decrease the use of fossil fuels.

\section{The National Reserve Forest Act B.E. 2507 (1964)}

It is well known that forests are the most important carbon sinks to absorb carbon in the atmosphere. In considering the Forest Act, it

34 The Promotion of Energy Conservation Act B.E. 2535 (1992) s 3.

35 Chacrit Sitdhiwej, "Laws in Thailand Promoting Renewable Energy," Journal of Energy and Natural Resources Law, Vol. 23, 2005, p. 205, 222.

36 The Energy Development and Promotion Act B.E. 2535 (1992) s 6. 
requires the Thai government to determine whether any forest in the territory is to be National Reserved Forest in order to preserve forest, forest products or natural resources, through the proclamation of Ministerial Regulations. ${ }^{37}$ It also stipulates that, within national reserved forest, no person can log, occupy and reclaim forest and collect forest products without permission of a national reserved forest's officer. ${ }^{38}$

\section{F. Institutional Arrangement for GHGs Emissions Reduction}

Implementation of the UNFCCC and the Kyoto Protocol has been promoted by Thailand's institutional arrangements. As a result of a Cabinet Resolution, in 2007, the TGO was established to be specifically responsible for implementing the GHGs emission reductions in Thailand and promoting a low carbon society. The TGO is similar to a technique and information center which manages GHGs emissions activities, investment, review of GHGs emissions reduction projects in accordance with the UNFCCC and Thailand's policy. Moreover, the TGO is functioned to be the representative agency for participating and negotiating benefits in international conferences on climate change.

\section{Participation and Negotiation in International Forums}

As Thailand's representative, the TGO has participated in many recent COPs to the UNFCCC in order to negotiate with the COP and prove Thailand's standpoint, roles and activities in mitigating GHGs emissions within the UNFCCC's framework. In relation to the Kyoto Protocol, the TGO attempted to offer the COP to review the CDM's modalities and procedures ${ }^{39}$, which is important for Thailand's CDM

37 National Reserve Forest Act B.E. 2507 (1964) s 6.

38 Ibid, s 14-16.

39 Thailand Greenhouse Gas Management Organization(Public Organization), "The Roles of TGO towards Negotiation" (24 September 2018), http:// www.tgo.or.th $/ 2015 /$ thai $/$ content.php?s1 $=9 \&$ s2 $=199 \&$ sub3 $=$ sub3. accessed 24 September 2018. 
investment because Thailand is a non-Annex I country. Accordingly, Thailand is required by the Kyoto Protocol to cooperate with the other Annex I countries to jointly develop the CDM so that Thailand will benefit from the transfer of technology.

The Paris Agreement has become a new agreement on climate change, adopted by COP 21, and requests all state parties to jointly agree with the same target and direction toward the reduction of GHGs emissions by aiming to limit an increase in global temperature below 2 degrees Celsius. Its Article 2 provides that "holding the increase in the global average temperature to well below $2{ }^{\circ} \mathrm{C}$ above pre-industrial levels and pursuing efforts to limit the temperature increase to $1.5^{\circ} \mathrm{C}$ above pre-industrial levels, recognizing that this would significantly reduce the risks and impacts of climate change" ${ }^{40}$ Thailand ratified the agreement on 21 September $2016 .{ }^{41}$ In this regard, the TGO suggested to the COP a guidance on cooperative approaches in Article 6 of the Paris Agreement. ${ }^{42}$ The TGO's guidance encourages the voluntary basis of cooperation with other state parties in CDM projects and ET, which have been promoted to respond to such a goal. Thailand would voluntarily obtain international assistance from other investing parties.

\section{Clean Development Mechanism (CDM)}

To implement the flexible mechanism provided by the Kyoto Protocol, the TGO is the main agency which establishes the requirements and screening for CDM projects. The projects shall be proposed with voluntary participation and be beneficial for GHGs emissions reduction leading to CERs that Annex I countries may use to be counted towards meeting their quantified emission limitation; moreover, the CDM projects should have additional operational impacts compared

40 See Paris Agreement, art 2 para 1(a). Full Text is here https: / unfccc.int/ sites/default/files/english_paris_agreement.pdf.

41 United Nations Treaty Collection, "Paris Agreement” (24 September 2018), https: / / treaties.un.org/Pages/ViewDetails.aspx?src=TREATY\&mtdsg no=XXVII-7-d\&chapter=27\&clang=_en. accessed 24 September 2018.

42 Thailand Greenhouse Gas Management Organization (Public Organization), above $n 41$. 
to the business-as-usual scenario in terms of the financial, investment, technological, and environmental aspects in accordance with sustainable development. ${ }^{43}$

The CDM projects can be categorized in three forms. Firstly, single projects in the 16 sectoral areas described in the Kyoto Protocol such as energy industries, energy distribution, transport, mining as well as mineral production, construction, and etc. ${ }^{44}$ Secondly, small-scale CDM projects provide a simplified project design document and methodologies for baseline determination and monitoring plans such as renewable energy project activities with a maximum output capacity equivalent of up to $15 \mathrm{MW}$, or energy efficiency improvement project activities that reduce energy consumption by up to $60 \mathrm{GW}$ per hour. ${ }^{45}$ Lastly, program of activities (POA) is a CDM concept of project modality which makes up CDM program activities (CPA); hence, multiple CPAs can be included under the same program of activities leading to lower transaction costs and shorter procedural steps. ${ }^{46}$

The TGO is the regulator controlling and managing the operation of CDM projects. The steps are: project proponents begin by requesting for project development and should then design the project design document (PDD) and identify its framework including the methods used to calculate and monitor GHGs emission reductions. ${ }^{47}$ When the PDD is validated and taken into consideration of the TGO, the TGO will check the proposed project against the requirements for registration and it will then be monitored and con-

43 Thailand Greenhouse Gas Management Organization (Public Organization), "GHG Reduction Project: CDM" (24 September 2018), http: / /www. tgo.or.th $/ 2015 /$ english/content.php?s1=33\&s2 =76. accessed 24 September 2018 .

44 Ibid.

45 Ibid.

46 Ibid.

47 Thailand Greenhouse Gas Management Organization (Public Organization), "GHG Reduction Project: Project Development" (24 September 2018), http://www.tgo.or.th/2015/english/content. php?s1=33\&s2=77\&sub3=sub3. accessed 24 September 2018. 
firmed to certify CERs. ${ }^{48}$ When the TGO's Executive Board receives the certification of GHGs emissions reduction, it shall consider the insurance of CERs to project proponents. ${ }^{49}$ These steps are under the TGO's inspection and control. From available statistics, the TGO have approved 148 registered projects and 35 projects of those received insurance of CERs totaling 3,525,515 $\mathrm{tCO}_{2}$ of GHGs emissions reduction..$^{50}$

\section{Emissions Trading (ET)}

We should think of how we can make a carbon market workable. This key question is at the heart of ET implementation because this mechanism is commonly regulated by market mechanisms allowing supply and demand to determine carbon prices and quantities. Such a carbon market is an incentive to decrease GHGs emissions where carbon credits are regarded as the commodity or goods that can be traded between buyers and sellers. Although Thailand has not enacted any laws to promote the carbon market, the TGO has recently attempted to create a voluntary carbon market. Like other countries, Thailand began its Emissions Trading Scheme (ETS) with the 'state' who became a leading actor to design the ETS by determining the 'cap setting' for registered industries contributing to GHGs emissions. The state will then provide 'allowance allocation' for those industries so that they shall limit their emissions by not exceeding the cap. $^{51}$

The industries registered under the ETS are obliged to annually report their allowance to the state. If any industries emitted GHGs exceeding their allowance, they must purchase additional allowance

48 Ibid.

49 Ibid.

50 Thailand Greenhouse Gas Management Organization (Public Organization), "GHG Reduction Project: Stat" (24 September 2018), http:/ / www. tgo.or.th $/ 2015$ / english / content.php?s1 $=33 \&$ s2 $=79 \&$ sub3 $=$ sub3. accessed 24 September 2018.

51 Thailand Greenhouse Gas Management Organization (Public Organization), “Thailand V-ETS” (25 September 2018), http: / / www.tgo.or.th / 2015 / thai $/$ content.php?s1=168s2=133. accessed 25 September 2018. 
from other industries in order to offset the GHGs emissions that exceeded their allowance..$^{52}$ This is called 'carbon offsetting'. In contrast, if any industries emitted GHGs lower than their allowance, they may roll over their excess allowance into the next year through the 'banking system', or they may sell their extra allowance to other industries. ${ }^{53}$ The TGO has developed and promoted the ETS as mentioned above, known as the 'Thailand Voluntary Emission Trading Scheme: Thailand V-ETS). V-ETS is a pilot system aiming to convince a variety of industries to willingly participate in the system. Nonetheless, by the lack of legally binding character, it is necessary for the TGO to take educational measures and increase public awareness in order to spread as much knowledge and understanding of the ETS as possible.

\section{Other Activities Relating to GHGs Emissions Reduction}

The TGO has been developing other projects in pursuit of GHGs emissions reduction. For example, the TGO created 'Crown Standard' for CDM projects which demonstrates potential to reduce GHGs; moreover, it also provides 'carbon label' to recognize any product that has been assessed for its carbon footprint. The TGO encourages people to buy products or goods with carbon labelling in order to convince industries or producers to tailor their production in recognition of global warming and other environmental problems.

\section{G. Conclusion}

As discussed in the introduction of this article, we have found efforts on behalf of Thailand which has lead to climate change mitigation in accordance with the international framework, although Thailand is not recognized as an industrial or developed country like the Annex I countries. Thailand has launched its policies and plans on GHGs emissions reduction which forms the national direction. In terms of the legal aspect, Thailand has not enacted any specific law directly 
addressing climate change, but its existing laws can be linked to the promotion of renewable energy use and carbon sinks, which are an appropriate way to reduce GHGs emissions. In addition, such policy and planning has now been substantially implemented by the TGO. This specialized agency has played key roles in various carbon-related activities such as the promotion and regulation of CDM projects, the creation of Thailand V-ETS, and other relevant activities.

\section{Bibliography}

Beder, Sharon, Environmental Principles and Policies: An Interdisciplinary Introduction, Earthscan, 2006.

Grossman, Margaret Rosso, "Climate Change and the Law," The American Journal of Comparative Law, Vol. 58, 2010.

Intergovernmental Panel on Climate Change, Climate Change 2013: The Physical Science Basis. Contribution of Working Group I to the Fifth Assessment Report of the Intergovernmental Panel on Climate Change, Cambridge University Press, 2013.

Intergovernmental Panel on Climate Change, "Organization" (1 August 2018), http://www.ipcc.ch/index.htm, accessed 1 August 2018.

Kiss, Alexandre and Dinah Shelton, Guide to International Environmental Law, Martinus Nijhoff Publisher, 2007.

Kiss, Alexandre and Dinah Shelton, Judicial Handbook on Environmental Law, UNEP, 2005.

Kyoto Protocol to the United Nations Framework Convention on Climate Change, opened for signature 16 March 1998, 37 ILM 22 (entered into force 16 February 2005).

Marks, Danny, "Climate Change and Thailand: Impacts and Response," Contemporary Southeast Asia, Vol. 33, Num. 2, 2011.

National Reserve Forest Act B.E. 2507 (1964).

Organization for Economic Co-operation and Development, Environmental Principles and Concepts, OCDE/ GD(95)124, Paris, 1995.

Sands, Philippe, Principles of International Environmental Law, second edition, Cambridge University Press, 2003. 
Sitdhiwej, Chacrit, "Laws in Thailand Promoting Renewable Energy," Journal of Energy and Natural Resources Law, Vol. 23, 2005.

Thailand Greenhouse Gas Management Organization (Public Organization), "Carbon Market/Carbon Credits and Carbon Market” (30 August 2018), http://www.tgo.or.th/2015/english/ content.php?s1=35\&s2=80. accessed 30 August 2018.

Thailand Greenhouse Gas Management Organization (Public Organization), "GHG Reduction Project: CDM" (24 September 2018), http:/ / www.tgo.or.th/2015/english/ content. php?s1=338s2=76. accessed 24 September 2018.

Thailand Greenhouse Gas Management Organization (Public Organization), "GHG Reduction Project: Project Development" (24 September 2018), http: / / www.tgo.or.th/2015 / english/ content. php?s1=33\&s2=77\&sub3=sub3 . accessed 24 September 2018.

Thailand Greenhouse Gas Management Organization (Public Organization), "GHG Reduction Project: Stat" (24 September 2018), http://www.tgo.or.th/2015/english/content. php?s1=33\&s2=79\&sub3=sub3. accessed 24 September 2018.

Thailand Greenhouse Gas Management Organization (Public Organization), "GHG Situation/Policies and Plans" (20 September 2018), http:/ / www.tgo.or.th/2015/english/content. php?s1=32\&s2=74\&sub3=sub3. accessed 20 September 2018.

Thailand Greenhouse Gas Management Organization (Public Organization), Nationally Appropriate Mitigation Actions, Thailand Greenhouse Gas Management Organization (Public Organization), 2015.

Thailand Greenhouse Gas Management Organization (Public Organization), "Thailand V-ETS” (25 September 2018), http: / / www. tgo.or.th $/ 2015 /$ thai $/$ content.php?s $1=16 \&$ s $2=133$. accessed 25 September 2018.

Thailand Greenhouse Gas Management Organization (Public Organization), "The Roles of TGO towards Negotiation" (24 September 2018), http://www.tgo.or.th/2015/thai/content. php?s1=9\&s2=199\&sub3=sub3. accessed 24 September 2018.

The Energy Development and Promotion Act B.E. 2535 (1992). 
The Promotion of Energy Conservation Act B.E. 2535 (1992).

United Nations Climate Changes, "Emissions Trading" (30 August 2018), https:/ / unfccc.int/ process/the-kyoto-protocol/ mechanisms/emissions-trading, accessed 10 September 2018.

United Nations Climate Changes, “Thailand” (10 September 2018), http://unfccc.int/tools_xml/country_TH.html, accessed 10 September 2018.

United Nations Climate Changes, "The Clean Development Mechanism” (10 September 2018), https://unfccc.int/process-andmeetings / the-kyoto-protocol/ mechanisms-under-the-kyotoprotocol/the-clean-development-mechanism, accessed 10 September 2018.

United Nations Framework Convention on Climate Change, opened for signature 4 June 1992, 1771 UNTS 107 (entered into force 21 March 1994)

United Nations Treaty Collection, "Paris Agreement" (24 September 2018), https://treaties.un.org/Pages/ViewDetails.aspx ?src $=$ TREATY $\&$ mtdsg_no $=$ XXVII- $7-$ $\mathrm{d} \&$ chapter $=27 \&$ clang=_en. accessed 24 September 2018.

World Health Organization, Climate Change and Human Health: Risks and Responses, World Health Organization, 2003. 